\title{
Lactate dehydrogenase activity of rat epididymis and spermatozoa: Effect of constant light
}

\author{
R.H. Ponce ${ }^{1,2}$, C.S. Carriazo ${ }^{2}$, and N.T. Vermouth ${ }^{2,3}$
}

${ }^{1}$ Cátedra de Química y Física Biológicas, Facultad de Odontología; ${ }^{2}$ Cátedra de Química Biológica, Facultad de Ciencias Médicas and ${ }^{3}$ Cátedra de Introducción a la Química y Física Biológicas, Facultad de Odontología. Universidad Nacional de Córdoba. Córdoba, Argentina

Accepted: 10/1/01

Key words: spermatozoa, epididymis, constant light, lactate dehydrogenase, fertility

\section{SUMMARY}

During its passage through the epididymis, the gamete undergoes a process of "maturation" leading to the acquisition of its fertilizing ability. The epididymis displays regional variations in the morphology and metabolic properties of its epithelium which are relevant for the progressive development of mature sperm characteristics. The epididymis has spontaneous peristaltic contractions and receives sympathetic innervation that is modulated by melatonin, a hormone synthesized and released by the pineal gland. Constant lighting disrupts melatonin synthesis and secretion. We have studied the effect of constant light on lactate dehydrogenase (LDH; EC 1.1.1.27) and its isozyme C4 activities and protein content in whole epididymis, epididymal tissue and in spermatozoa from caput and cauda segments. Animals were exposed from birth to an illumination schedule of $14 \mathrm{~h}$ light: 10 h dark (group L:D). At 60 days of age one group of animals was submitted to constant light over 50 days (group L:L). In order to test the fertilizing ability, the rats of each group were mated with soliciting estrous females. The percentage of pregnancies in females mated with males maintained in
L:L was remarkably lower than those in females mated with males maintained in the L:D photoperiod ( $44 \%$ and $88 \%$ respectively). Constant light increased protein concentration and LDH activity in caput as well as in cauda of total epididymis. On the contrary, in epididymal tissue, the protein content decreased in both epididymal sections compared with controls. When enzymatic activity was expressed in Units per spermatozoa, constant light induced a significant reduction of total $\mathrm{LDH}$ and $\mathrm{LDHC}_{4}$ in caput and cauda spermatozoa while LDH activity of epididymal tissue was not affected. In spite of the decrease in LDH per sperm cell when rats were exposed to constant light, in total epididymis (epididymis tissue plus sperm cells content) and in spermatozoa, values of enzyme activities expressed per weight unit were higher than those of controls. This is explained by the increase in the amount of stored spermatozoa, both in caput and cauda, produced by exposure of animals to constant light.

Our results confirm that in rats, chronic exposure to constant light promotes a reduction of fertilizing ability and indicates that continuous lighting reduces the total $\mathrm{LDH}$ and $\mathrm{LDHC}_{4}$ activities, possibly due to moderate aging of spermatozoa with- 
in the duct by lengthening of the sperm transit through the epididymis.

\section{INTRODUCTION}

Mammalian spermatozoa are known to undergo important morphological, physiological and biochemical modifications after leaving the testes and during their transit through the male reproductive tract (Bedford, 1990; Yanagimachi, 1994). During its passage through the epididymis, gamete undergoes a process of "maturation" leading to the acquisition of its fertilizing ability (Orgebin-Crist and Olson, 1984; Cooper, 1986; Robaire and Hermo, 1988). Some changes in the spermatozoa during maturation such as, protein content (Lavon et al., 1971; Vermouth et al., 1986), lipid content and composition (Aveldaño et al., 1992), and enzyme activities (Vermouth et al., 1986) were demonstrated in rat.

The epididymis displays regional variations in the morphology and metabolic properties of its epithelium (Hamilton, D.W., 1975), which are relevant for the progressive development of mature sperm characteristics. This duct has spontaneous peristaltic contractions and receives sympathetic innervation (Hib, 1976). The surgical removal of the inferior mesenteric ganglion and proximal hypogastric nerves produces significant changes in epididymal sperm transport, sperm motility and luminal fluid proteins composition (Ricker et al., 1997). On the other hand, it is known that sympathetic neurotransmission is modulated by melatonin, a hormone synthesized and released by the pineal gland (Wurtman, 1967).

The hormonal activity of the pineal gland plays the role of internal timer for several daily and seasonal phenomena (Reiter, 1991; Hardeland and Rodriguez, 1995) and appears to exert an important role in neuroendocrine regulation. Melatonin apparently affects the reproductive function at the hypothalamic-pituitary level by inhibition of the hypothalamic pulsatile secretion of gonadotrophin releasing hormone. This also takes place at the gonadal level where melatonin receptors have been found. Moreover, maternal pineal influences the gonadal development and function of rat offspring (Jarrige and Boucher, 1992; Vermouth et al., 1995).
Although the rat is a non-seasonal breeder, its reproductive function is influenced by the photoperiod, melatonin administration or pinealectomy. It has been demonstrated that melatonin synthesis is suppressed by constant lighting (Moore and Klein, 1974; Reiter, 1981). Light acts as a selective inhibitor of hydroxyindole-o-methyl transferase (HIOMT), which is required for melatonin synthesis (Wurtman et al., 1963). Earlier work conducted by us in rat testis (Vermouth et al., 1984) have shown that constant light disrupts the circadian variation of lactate dehydrogenase isozyme $\mathrm{C}_{4}$ (LDHC4), a sperm-specific isozyme (Blanco et al., 1975; Blanco, 1991). Moreover, Carneiro et al. (1991) showed in the rat that the circadian rhythm of vas deferens contraction is abolished when melatonin synthesis is suppressed by constant lighting.

One question arising from these studies regards whether melatonin suppression influences the epididymis and the spermatozoa enzymatic activity. In the present study we have suppressed rat melatonin synthesis by constant light. Lactate dehydrogenase (LDH: EC 1.1.1.27) and protein content were analyzed in whole epididymis, epididymal tissue separated from spermatozoa and in sperm cells of rats chronically exposed to constant light. We show that constant light induced a reduction of total $\mathrm{LDH}$ and $\mathrm{LDHC}_{4}$ per epididymal spermatozoa while total LDH activity of epididymal tissue was not affected.

\section{MATERIALS AND METHODS}

\section{Animals}

Sexually rested male Wistar rats were kept in a temperature-controlled room $\left(23 \pm 2^{\circ} \mathrm{C}\right)$, housed in groups of five in cages with water and food (standard lab chow) "ad libitum". Control rats were kept in a light-dark cycle of $14 \mathrm{~h}$ light and 10 $\mathrm{h}$ of darkness. The lights on phase was from 06:00 to 20:00 h. During the light period, light intensity was 150-200 lux at the level of the cages. These animals were designated as group L:D. The experimental group was composed by animals maintained from birth in the same conditions as controls, but exposed from the age of 60 days to constant light (L:L) for 50 days. Approximately onehalf of the rats of each group was used to test the fertilizing ability. 


\section{Preparation of extracts}

Animals were sacrificed by decapitation at 10:00 $h$ because the lowest level of enzymatic LDH rhythm was observed at this time (unpublished results).

Epididymis were removed and carefully dissected to eliminate adventitious tissue. Each epididymis was sectioned into three segments: proximal (caput), medial (corpus) and distal (cauda). Corpus was discarded. Segments (caput and cauda) of one epididymis from each animal were cut into pieces of approximately $1 \mathrm{~mm}^{3}$ and suspended in a $\mathrm{pH} 7.4$ solution containing $115 \mathrm{mM} \mathrm{NaCl}, 5 \mathrm{mM} \mathrm{KCl}, 3$ $\mathrm{mM} \mathrm{MgCl} 2.6 \mathrm{H}_{2} \mathrm{O}, 15 \mathrm{mM} \mathrm{NaH} \mathrm{PO}_{4} . \mathrm{H}_{2} \mathrm{O}, 1 \mathrm{mM}$ ethylenediamine tetraacetic (EDTA) and $20 \mathrm{mM}$ Tris. After gentle stirring at $30^{\circ} \mathrm{C}$ for 5-6 min, the suspension was filtered through a silk cloth. The debris retained in the cloth was washed four times with the same solution in order to recover as many spermatozoa as possible. The filtrates were centrifuged at $800 \mathrm{~g}$ for $10 \mathrm{~min}$ at room temperature. The low centrifugation speed maintained spermatozoa integrity. The absolute quantity of spermatozoa content in caput or cauda epididymis is a critical value because it is subject to loss in the extraction procedure.

The pellet of spermatozoa was washed with 10 parts of the solution, centrifuged as indicated above and finally resuspended in $5 \mathrm{ml}$ of buffer solution. An aliquot of this suspension, appropriately diluted with $0.15 \mathrm{M} \mathrm{NaCl}$ in $0.2 \%$ formaldehyde, was used to count spermatozoa in a haemocytometer in triplicate. The remaining fraction of sperm suspension was centrifuged at $13,000 \mathrm{~g}$ for $15 \mathrm{~min}$ at $4^{\circ} \mathrm{C}$. The pellet was weighed and resuspended to obtain a final concentration of $10-20 \times 10^{6}$ cells per ml. The sperm suspension was homogenized by ultrasonic treatment on ice (four $70 \mathrm{~W}$ pulses of $15 \mathrm{sec}$ each at $10 \mathrm{sec}$ intervals, in a Branson Sonic Power Co. Sonifier B-12). Total disruption of cells was checked by light microscopy. The sperm suspension were centrifuged at $13,000 \mathrm{~g}$ for $30 \mathrm{~min}$ at $4^{\circ} \mathrm{C}$ and supernatants were used for the studies.

The epididymal tissue remaining in the cloth was repeatedly rinsed with the $\mathrm{pH} 7.4$ solution until it was freed of spermatozoa. The washed tissue was weighed and suspended in 9 parts of distilled water $(1: 10, W: V)$ and homogenized. The suspension was centrifuged at $13,000 \mathrm{~g}$ for $30 \mathrm{~min}$ at $4^{\circ} \mathrm{C}$ and the supernatant was used for the studies.
Segments (caput and cauda) of the opposite epididymis from each animal with their spermatozoa content were cut into pieces as described previously and followed the same procedure as indicated for the sections free of germ cells. Extracts from epididymis including the spermatozoa will be designated as "total epididymis" and those from washed epididymis without spermatozoa as "epididymal tissue".

\section{Enzyme assays}

Total lactate dehydrogenase was determined by the method of Wroblewski and La Due (1955), using $0.5 \mathrm{mM}$ sodium pyruvate as substrate; lactate dehydrogenase isozyme $\mathrm{C}_{4}$ was assayed with the same method by using $5.0 \mathrm{mM} \alpha$-keto-glutarate as substrate. This substrate allows a selective determination of rat $\mathrm{LDHC}_{4}$ in mixtures containing other molecular forms of lactate dehydrogenase (Shatz and Segal, 1969; Coronel et al., 1983). The assays were performed at $37^{\circ} \mathrm{C}$. Change of absorbance at $340 \mathrm{~nm}$ was measured for $3 \mathrm{~min}$. One unit of enzyme is the amount producing a $\Delta \mathrm{E}_{340}$ of 2.07 per min, which corresponds to the oxidation of $1 \mu$ mole of NADH.

\section{Protein determination}

Soluble protein concentration was determined with the method of Lowry et al. (1951), using bovine serum albumin (Frac. V) as standard.

\section{Control of spermatozoa contamination in the epididymis tissue}

Total $\mathrm{LDH}$ and $\mathrm{LDHC}_{4}$ activities were determined in epididymal tissue. Relative activity of pure rat $\mathrm{LDHC}_{4}$ with different substrates has been determined in our laboratory (Coronel et al., 1983). The ratio of activity assayed with $0.5 \mathrm{mM}$ pyruvate over that determined with $5.0 \mathrm{mM} \alpha$-ketoglutarate is 4.12 for rat $\mathrm{LDHC}_{4}$. Thus, knowing the activity of a given amount of $\mathrm{LDHC}_{4}$ with $5.0 \mathrm{mM} \alpha$-ketoglutarate, it is posible to estimate that to be obtained if the assay were performed with $0.5 \mathrm{mM}$ pyruvate as substrate. By relating this calculated $\mathrm{LDHC}_{4}$ activity with total lactate dehydrogenase $(0.5 \mathrm{mM}$ pyruvate), an estimation of enzyme contamination from spermatozoa can be made in epididymal tissue. The percentage of LDH activity belonging to spermatozoa contamination in all experiments described gave a value lower than $5 \%$. 


\section{Fertilizing ability test}

To test the fertility, male rats maintained in L:D cycle or L:L were individually placed in separate cages with a soliciting estrous female for 24 hours. After this period, females were caged individually. In each case, the test was considered positive when the female became pregnant.

\section{Statistical analysis}

Student's t test was used to estimate significance of differences between two mean values; statistical significance was set at $\mathrm{P}<0.05$.

\section{RESULTS}

Mammalian spermatozoa volume changes while passing through the epididymal duct (Laufer et al., 1979). Thus, to compare the protein content and the enzyme activity between the germ cells from caput and cauda segments, we prefer to express the results per $10^{9}$ spermatozoa or per gram of gamete.

\section{Soluble protein concentration}

\section{Epididymis}

Constant light exposure over 50 days produced a significant protein concentration increase in caput $(\mathrm{P}<0.05)$ and cauda $(\mathrm{P}<0.001)$ of total epididymis (Fig. 1A). On the contrary, in epididymal tissue the protein concentration fell in both sections compared to that of animals in L:D $(\mathrm{P}<0.05)$ (Fig. 1B). Moreover, in both groups (L:D and L:L) the protein concentration per gram of wet tissue in caput was similar to that of cauda, either in total epididymis (Fig. 1A) or in epididymis free of spermatozoa (epididymal tissue) (Fig. 1B).

\section{Spermatozoa}

In the L:L group, the protein content per gamete expressed as mg x $10^{9}$ spermatozoa fell about $60 \%$ from caput to cauda $(\mathrm{P}<0.001)$ (Fig. 1C) in a similar way to that of the group L:D.

On the other hand, when results were expressed as $\mathrm{mg} / \mathrm{gram}$ of cells, the constant light induced an increment of protein content in spermatozoa of both epididymal segments $(\mathrm{P}<0.001)$ compared with those from control animals (Fig. 1D). In groups L:D and $L: L$, the protein values in spermatozoa of caput were similar to those in spermatozoa from cauda.

\section{Enzyme activity}

\section{Epididymis}

In animals maintained in constant light, the LDH activity showed an increment in caput $(\mathrm{P}<0.001)$ and cauda $(\mathrm{P}<0.05)$ of total epididymis (Fig. 2A). Also, LDH activity in total epididymis (Fig. 2A) and epididymal tissue (Fig. 2B) showed higher values in cauda than in caput $(\mathrm{P}<0.001)$ in both animal groups.

\section{Spermatozoa}

When enzymatic activity was expressed in Units per $10^{9}$ spermatozoa, animals maintained in constant light showed a significant reduction of total $\mathrm{LDH}(\mathrm{P}<0.01)$ and $\mathrm{LDHC}_{4}(\mathrm{P}<0.001)$ in spermatozoa from caput and cauda (Fig. 2C and 3A, respectively) compared with control group. Gametes from caput showed the highest value of total LDH $(\mathrm{P}<0.01)$ and $\mathrm{LDHC}_{4}(\mathrm{P}<0.001)$ activities (Fig. $2 \mathrm{C}$ and $3 \mathrm{~A}$, respectively). In the control group, the decrease of enzyme activities in the distal portion was $37 \%$ and $40 \%$ for total $\mathrm{LDH}$ and $\mathrm{LDHC}_{4}$, respectively. In spermatozoa of group $\mathrm{L}: \mathrm{L}$, the total $\mathrm{LDH}$ and $\mathrm{LDHC}_{4}$ activities fall $36 \%$ during its epididymal maturation from caput to cauda.

On the other hand, when the results were expressed as units/gram of cells, constant light induced an increment of total $\mathrm{LDH}$ and $\mathrm{LDHC}_{4}$ activities in spermatozoa from caput and cauda epididymis (Fig. 2D and 3B). Also, in groups L:D and L:L, total LDH and LDHC4 activities in cauda spermatozoa were higher than those in caput $(\mathrm{P}<0.001$ and $\mathrm{P}<0.05$, respectively).

By calculating the ratio between enzymatic activity values, expressed as units $/ 10^{9}$ spermatozoa and units/gram spermatozoa, it is possible to know approximately the spermatozoa mass ( $\mathrm{g} / 10^{9}$ cells) in each epididymal segment. Both groups showed that the mass is significantly higher in caput than in cauda $(\mathrm{P}<0.05)$. However, spermatozoa mass values in group L:L (caput:0.56 \pm 0.06 ; cauda: $0.24 \pm 0.05$ ) were notably lower than those of group L:D (caput: $0.98 \pm 0.05$ and cauda: $0.55 \pm 0.07$ ). These results showed a reduction of $47 \%$ and $56 \%$ in caput and cauda segments, respectively $(\mathrm{P}<0.01)$.

\section{Fertilizing ability}

Results of fertility tests are summarized in Table I. The percentage of pregnancies in females mated 
A

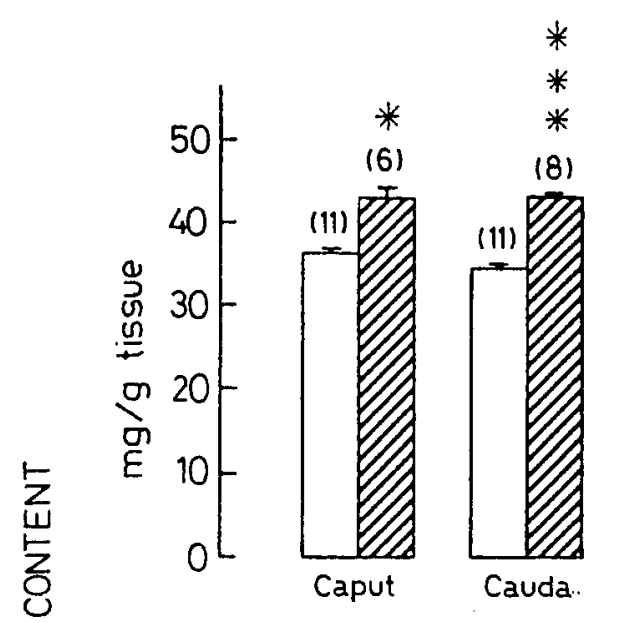

C

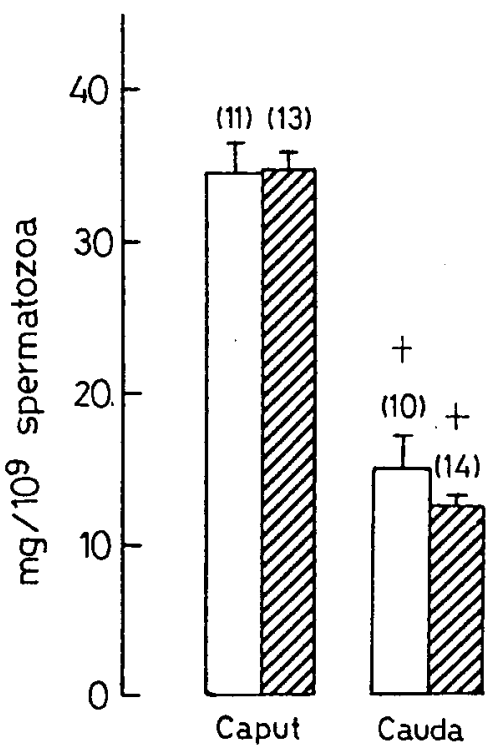

with males maintained in L:L was remarkably lower than those in females mated with males under L:D photoperiod (44\% and $88 \%$ respectively).

\section{DISCUSSION}

It is clear that mammalian spermatozoa undergo an essential and rather complicated process of maturation as they pass through the epididymis. Once maturation is complete, spermatozoa are maintained in the cauda epididymides before being
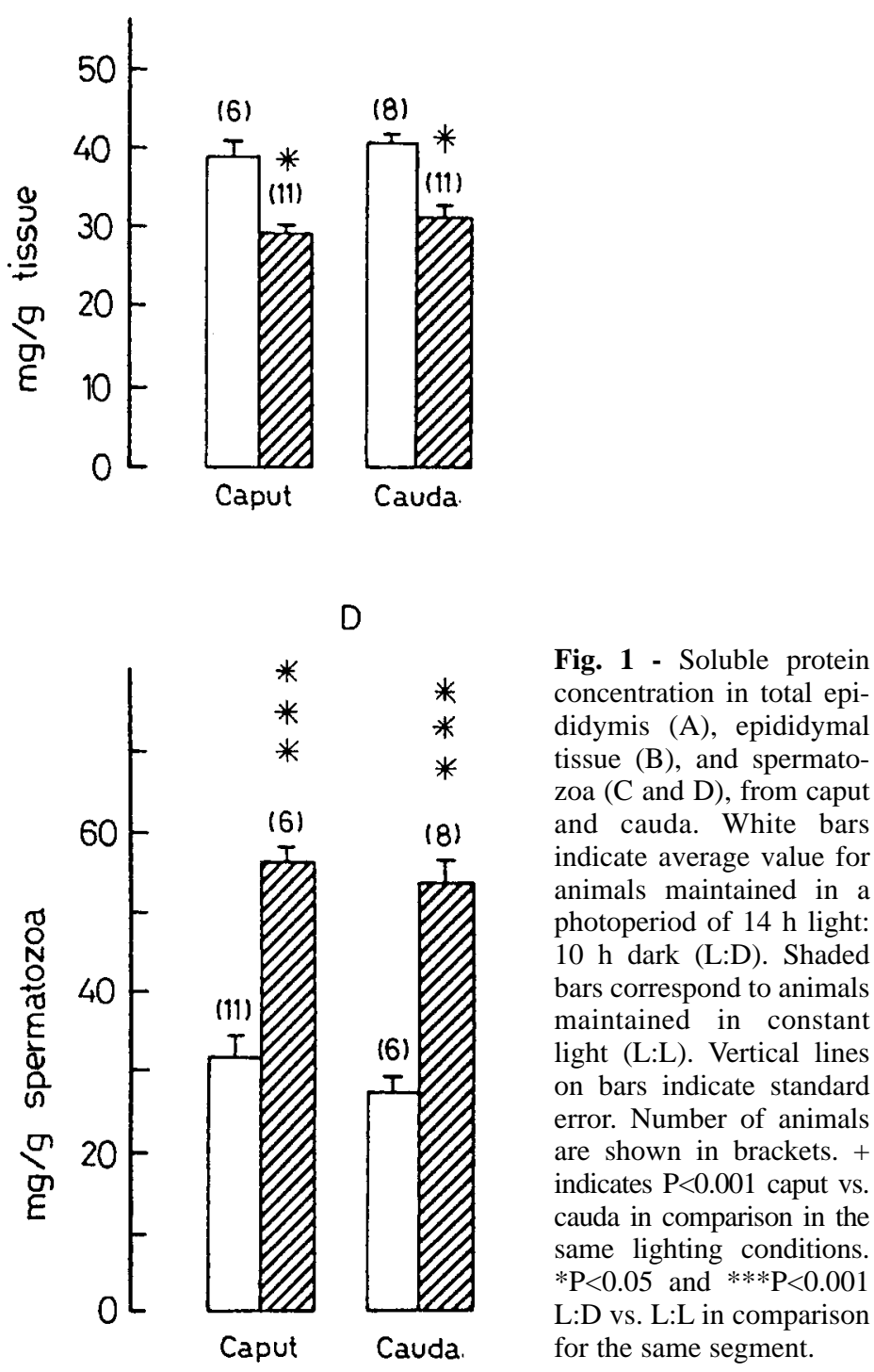

expelled as a result of ejaculation into the ejaculatory duct. In the epididymis, sperm maturation occurs during storage prior to ejaculation. It is reasonable to assume that the time spent by spermatozoa in passing along the epididymal duct is related to these events. In the present study, constant light exposure, affected the fecundity of the male rats after natural mating, since their breeding rate was lower than those of untreated animals. Similar results have been reported by Fantie et al. (1984), who described a sexual behavior disrup- 
A

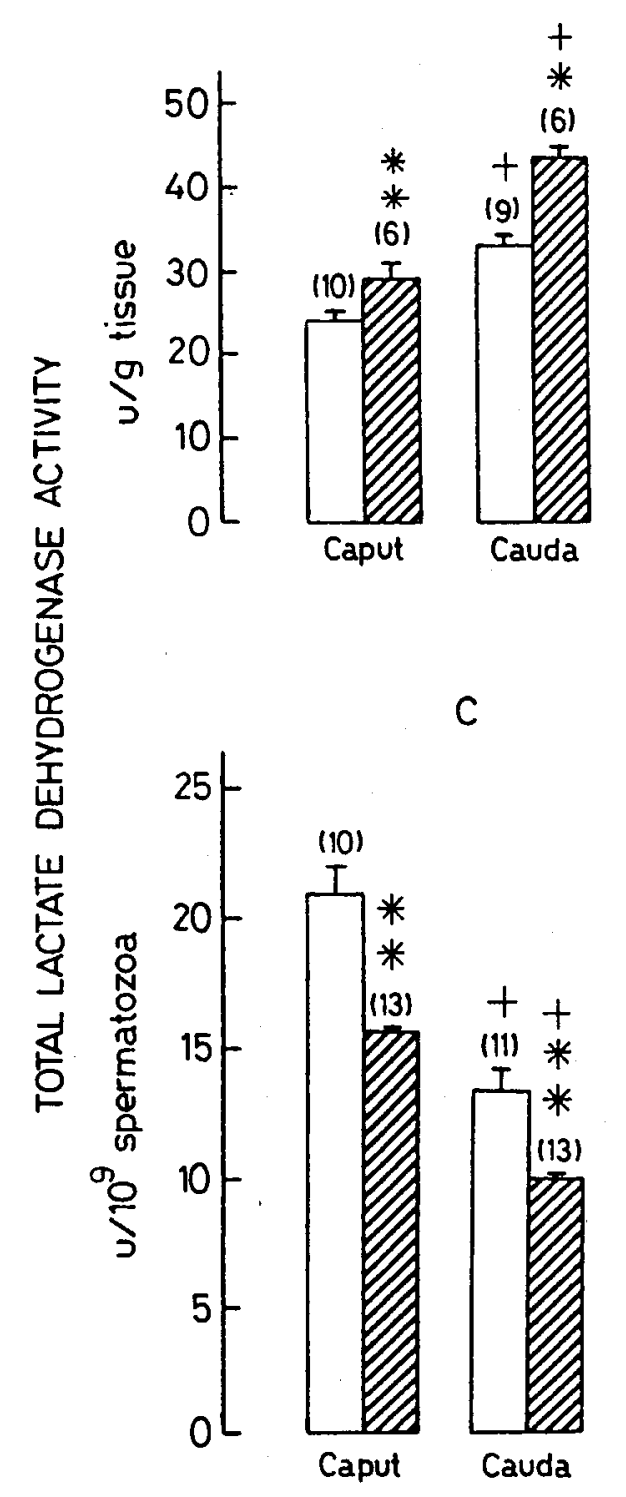

B

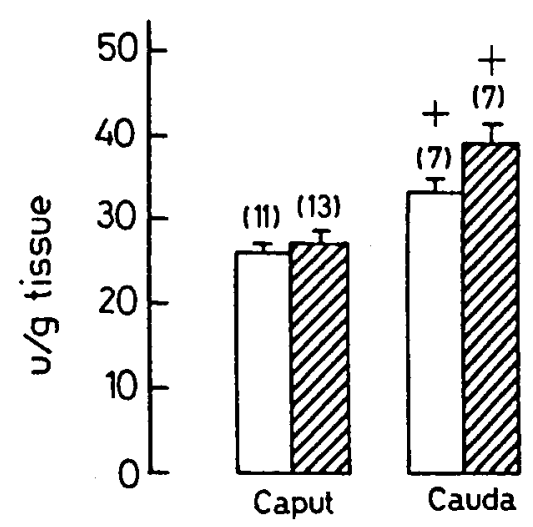

D

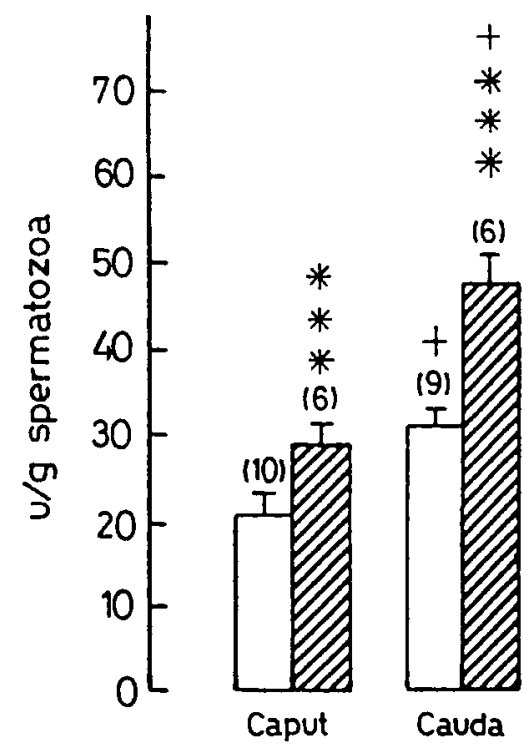

Fig. 2 - Total lactate dehydrogenase activity in total epididymis (A), epididymal tissue (B), and spermatozoa (C and $\mathrm{D})$, from caput and cauda. White bars indicate average value for animals maintained in a photoperiod of $14 \mathrm{~h}$ light: $10 \mathrm{~h}$ dark (L:D). Shaded bars correspond to animals maintained in constant light (L:L). Vertical lines on bars indicate standard error. Number of animals are shown in brackets. + indicates $\mathrm{P}<0.001$ caput vs. cauda in comparisons. $* \mathrm{P}<0.05, * * \mathrm{P}<0.01$ and $* * * \mathrm{P}<0.001 \mathrm{~L}: \mathrm{D}$ vs. $\mathrm{L}: \mathrm{L}$ in comparisons. tion in animals exposed to constant white light for 60-90 days. Disruption of hormonal and behavioral rhythms could cause a deficit in rat ejaculation by disorganizing general activity rhythms. However, the mechanisms underlying these changes are not understood.

Spontaneous epididymal contractility is a factor that enables sperm migration, while transit time is determined by the frequency of contractions (Cosentino and Cockett, 1986; Robaire and Hermo, 1988). This duct receives sympathetic innervation from the inferior mesenteric ganglion and its surgi- cal removal produces significant changes in epididymal sperm transport, sperm motility and luminal fluid protein composition (Ricker et al., 1997). In addition, surgical sympathectomy increases the transit time and the number of spermatozoa in the cauda epididymis (Kempinas et al.,1998b). On the other hand, in the prostatic portion of rat vas deferens, melatonin potentiates sympathetic neurotransmission by increasing contractions in response to noradrenaline and ATP released by acetylcholine stimulation of presynaptic nicotinic receptors (Carneiro et al., 1994). The impairing 
A

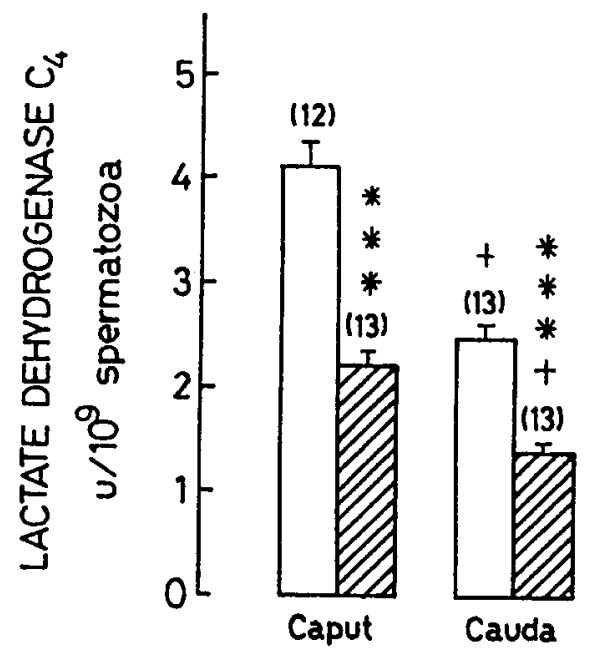

pineal nocturnal secretion of melatonin by constant light abolishes the daily variation in the maximal acetycholine-induced contraction of vas deferens (Carneiro et al., 1991, 1993). Thus, it seems that a suppression of melatonin secretion by constant light could reduce the epididymal contractions, and consequently, the transit time along the epididymis would be increased. This is detrimental for sperm maturation and results in the releasing of non-fertile spermatozoa into the ejaculate. Our experiments also demonstrated that in animals exposed to continuous illumination, the $\mathrm{LDHC}_{4}$ activity per epididymal gamete decreased by $57 \%$ compared with controls. It is known that $\mathrm{LDHC}_{4}$ is a component of shuttles that transfer reducing equivalents from cytosol to mitochondria (Burgos et al., 1982; Coronel et al., 1986) and play an important role when gametes utilize glycolytic substrates in aerobiosis. Therefore, a decrease of enzymatic activity per individual gamete induced by constant light could be a consequence of delayed sperm transport through the epididymal duct. The biochemical changes that sperm undergo during their epididymal transit enable them to fertilize a mature oocyte. Alternatively, the low fertility rates of light-treated males would be also attributable to sperm metabolic conditions. Whether the significant reduction in the spermatozoa specific enzyme activity implies changes in its fertilizing ability remains to be elucidated.
B

Fig. 3 - Lactate dehydrogenase isozyme $\mathrm{C}_{4}$ activity in spermatozoa (A and B) from caput and cauda. White bars indicate average value for animals maintained in a photoperiod of $14 \mathrm{~h}$ light: $10 \mathrm{~h}$ dark (L:D). Shaded bars correspond to animals maintained in constant light (L:L). Vertical lines on bars indicate standard error. Number of animals are shown in brackets. + indicates $\mathrm{P}<0.001$ caput vs. cauda in comparisons. $* \mathrm{P}<0.05, \quad * * * \mathrm{P}<0.001$ L:D vs. L:L in comparisons.
On the other hand, there were no effects on protein content of spermatozoa from epididymal segments of rats treated with constant light. However, there was a decrease of protein concentration in epididymal tissue free of spermatozoa in animals exposed to constant light (Fig. 1B). Relatively little is known about the effects of melatonin in this tissue, but there is some evidence for a correlation between melatonin modulation of sympathetic neurotransmission and protein synthesis. In this regard, Carneiro et al. (1994) showed that melatonin decreases $\left.{ }^{[35} S\right]$ methionine incorporation in the hypogastric ganglion-prostatic vas deferens preparation. This suggests that melatonin modulates the presynaptic nicotinic response and also controls the trophic neuronal influence on smooth muscle cells. The protein content in epididymal tissue free of spermatozoa in group L:L (Fig. 1B) was lower than that in control animals, while protein content per gamete did not differ significantly from the levels of untreated rats (Fig. 1C). Therefore, we may assume that the increment of protein content in total epididymis of group L:L (Fig. 1A) could be explained by an increased number of spermatozoa. A similar finding was described after surgical removal of the rat inferior mesenteric ganglia (Billups et al., 1991). The results of these authors were interpreted as an increase of sperm transit time and retention of gametes within the epididymis. Thus, our results in animals exposed to 
Table I

Breeding performance of male rats in different lighting conditions

\begin{tabular}{cccc}
\hline Group & Number of males & Number of females & Number of pregnancies \\
\hline L:D & 17 & 17 & $15(88 \%)$ \\
L:L & 18 & 18 & $8(44 \%)$ \\
\hline
\end{tabular}

L:D: 14 h light:10 h darkness; L:L: constant light.

constant light are comparable to that observed after inferior mesenteric ganglia ablation. This suggests an accumulation of epididymal sperm as a result of a delayed sperm transport by reduction of the epididymal contraction.

Also, it may be considered that the enhanced sperm number in the epididymal duct from group L:L reflects an increase of spermatozoa production by the testis. Testosterone is one of the requirements to maintain normal spermatogenesis. Because plasma testosterone levels were not found to be significantly altered in rat by continuous illumination (Fantie et al., 1984), daily spermatozoa production probably was not affected. Furthermore, rat testis daily spermatozoa production remained unchanged when guanethidine selectively blocked sympathetic noradrenergic neurons. This treatment also induced a significant increase in sperm number in cauda epididymis (Kempinas et al., 1998a). In addition, in a previous study we have shown that there was no significant difference in $\mathrm{LDHC}_{4}$ activity rat testis between groups L:D and L:L (Vermouth et al., 1984). For instance, there are no antecedents to presume that constant light affects rat testis daily spermatozoa production.

On the other hand, in group L:L, the slowing down of sperm transit could be related to alterations in fluid secretion in the epididymal duct. In this respect, it is known that chemical-induced sympathectomy prevents fructose secretion in prostate and seminal vesicle of rats (Lamano et al., 1990). Moreover, previous works in our laboratory have shown that chronic exposure of rats to constant light promotes an alteration in sympathetic parotid and submaxillary glands secretory response (Chiarenza et al., 1989; Gallará and Bellavía, 1995). Whatever the effect of continuous lighting on the secretory activity of the epididymis it remains to be elucidated.

In addition, we found that by expressing the pro- tein content and enzymatic activity as per gram of spermatozoa, both values showed a significant increase in group L:L, while the estimated spermatozoa mass of group L:L was lower than that of group L:D. These findings could be explained by an enhanced number of cells per gram of gametes. In this case, it is known that as spermatozoa mature through the epididymal duct, they undergo a cytoplasmic loss, and the cellular volume decreases while the density increases (Lindahl and Thungvist, 1965; Laufer et al., 1979). Thus, our findings hardly suggest a moderate gamete size reduction by aging phenomena in spermatozoa of the epididymal duct. These results are in agreement with data reported by Cuasnicu and Bedford (1989) demonstrating, in hamster, a closer correlation between restrained aging sperm and a reduced ability to fertilize an oocyte. This leaves us with the intriguing question whether periodic melatonin treatment would restore the gamete transit through epididymis and, as a consequence, fertilizing ability. Our results would appear to be of biological significance for human reproduction, with changes in the melatonin level following night-shift work, physical stress and sleep disorders (Monteleone et al., 1992; Dawson and Encel, 1993; Arendt et al., 1997).

In conclusion, the present study provides yet another piece of evidence that chronic exposure to constant light promotes a low fertilization performance, presumably by decreasing epididymal contractility. Thus, slowing down gamete transit through epididymis would be accomplished by a reduction of spermatozoa LDH activity possibly due to a moderate aging of spermatozoa within the duct. Whether the significant caput and cauda reduction in the sperm specific enzyme $\mathrm{LDHC}_{4}$ activity implies changes in the fertilizing ability of spermatozoa remains to be elucidated. 


\section{ACKNOWLEDGEMENTS}

This study was supported, in part, by grants from the Consejo Nacional de Investigaciones Científicas y Técnicas (CONICET) of Argentina, and the Consejo de Investigaciones Científicas y Tecnológicas de la Provincia de Córdoba (CONICOR). The authors wish to express their gratitude to Dr. A. Blanco, for his advice and revision of the manuscript. N.T.V. is a Career Investigator of the CONICET.

\section{REFERENCES}

Arendt J., Skene D.J., Middleton B., Lockley S.W., and Deacon S.: Efficacy of melatonin treatment in jet lag, shift work and blindness. J. Biol. Rhythm 12, 604-617, 1997.

Aveldaño M.I., Rotstein N.P., and Vermouth N.T.: Lipid remodeling during epididymal maturation of rat spermatozoa. Biochem. J. 283, 235-241, 1992.

Bedford J.M.: Sperm dynamics in the epididymis. In Gamete Physiology. (Eds. Asch, R.H., Balmaceda, J.P. and Johnston, I.), Serono Symposia, USA, Nowell, Massachusetts, pp. 5367, 1990.

Billups K.L., Tillman S.L., and Chang T.S.K..: Ablation of the inferior mesenteric plexus in the rat: alteration of sperm storage in the epididymis and vas deferens. J. Urol. 143, 625-629, 1991.

Blanco A., Zinkhan W.H., and Walker D.G.: LDH-X: cellular localization, catalytic properties and genetic control of synthesis. In Isozymes, vol. 3. (Ed. Markert, C.L.). Academic Press, New York, pp. 297-312, 1975

Blanco A.: Functional significance of the testis and spermspecific lactate dehydrogenase isozyme $\left(\mathrm{LDHC}_{4}\right)$. Academia Nacional de Ciencias (Córdoba, Argentina), Miscelánea 84, 133, 1991.

Burgos C., Coronel C.E., Gerez de Burgos N.M., Rovai L.E., and Blanco A.: Studies in vitro on shuttle systems of mouse spermatozoa. Biochem. J. 208, 413-417, 1982.

Carneiro R.C.G., Cipolla-Netto J., and Markus R.P.: Diurnal variation of the rat vas deferens contraction induced by stimulation of presynaptic nicotinic receptors and pineal function. J. Pharmacol. Exp. Ther. 259, 614-619, 1991.

Carneiro R.C.G., Pereira E.P., Cipolla-Neto J., and Markus R.P.: Age-related changes in melatonin modulation of sympathetic neurotransmission. J. Pharmacol. Exp. Ther. 266, 15361540, 1993.

Carneiro R.C.G., Toffoleto O., Cipolla-Neto J., and Markus R.P.: Modulation of sympathetic neurotransmission by melatonin. Eur. J. Pharmacol. 257, 73-77, 1994.

Coronel C.E., Burgos C., Gerez de Burgos N.M., Rovai L.E., and Blanco A.: Catalytic properties of the spem-specific lac- tate dehydrogenase (LDHX or $\mathrm{C}_{4}$ ) from different species. J. exp. Zool. 225, 379-385, 1983.

Coronel C.E., Gallina F.G., Gerez de Burgos N.M., Burgos C., and Blanco A.: Properties of the branched-chain 2hydroxyacid/ 2-oxoacid shuttle in mouse spermatozoa. Biochem. J. 235, 853-858, 1986.

Cosentino M.J., and Cockett A.T.K.: Structure and function of the epididymis. Urol. Res. 14, 229-240, 1986.

Cooper T.G.: The epididymis, sperm maturation and fertilization. (Ed. Cooper T.G.), New York, Springer-Verlag Berlin, Heidelberg, pp. 1-281, 1986.

Cuasnicú P.S., and Bedford J.M.: The effect of moderate epididymal aging on the kinetics of the acrosome reaction and fertilizing ability of hamster spermatozoa. Biol. Reprod. 40, 1067-73, 1989.

Chiarenza A.P., Sanz E.G., Vermouth N.T., Aoki A., and Bellavía S.L.: Effect of continuous light on rat parotid gland structure and reactivity. Anat. Embryol. 179, 497-501, 1989.

Dawson D., and Encel N.: Melatonin and sleep in humans. J. Pineal Res. 15, 1-12, 1993.

Fantie B.D., Brown R.E., and Moger W. H.: Constant lighting conditions affect sexual behavior and hormone levels in adult male rats. J. Reprod. Fertil. 72, 435-441, 1984.

Gallará R.V., and Bellavía S.L.: Modification of the $\beta$-adrenergic sensitivity of rat submandibular gland by constant light. Archs. oral Biol. 40, 73-77, 1995.

Goldberg E.: Inmunochemical specificity of lactate dehydrogenase X. Proc. Nat. Acad. Sci. 68, 349-353, 1971.

Hamilton D.W.: Structure and function of the epithelium lining the ductuli efferentes, ductus epididymis and ductus deferens in the rat. In Handbook of Physiology, sect. 7, Endocrinology, vol. 5. (Eds. Hamilton, D.W. and Greep, R.O.), American Physiological Society, Bethesda, pp. 259-301, 1975.

Hardeland R., and Rodriguez C.: Versatile melatonin: A pervasive molecule serves various functions in signaling and protection. Chronobiol. Int. 12, 157-165, 1995.

Hib J.: Effects of autonomic drugs on epididymal contractions. Fertil. Steril. 27, 951-956, 1976.

Jarrige J.F., and Boucher D.: Influence of the maternal pineal gland on the testicular function in rats. Ann. Endocrinol. (París) 53, 67-70, 1992

Kempinas W. G., Suarez J.D., Roberts N.L., Strader L.F., Ferrell J., Goldman J.M., Narotsky M.G., Perreault S.D., Evenson D.P., Ricker D.D., and Klinefelter G.R.: Fertility of rat epididymal sperm after chemically and surgically induced sympathectomy. Biol. Reprod. 59, 897-904, 1998a.

Kempinas W. G., Suarez J.D., Roberts N.L., Strader L., Ferrell J., Goldman J.M., and Klinefelter G.R.: Rat epididymal sperm quantity, quality and transit time after guanethidineinduced sympathectomy. Biol. Reprod. 59, 890-896, 1998 b.

Lamano Carvalho T.L., Petenusci S.O., Favaretto A.L.V., and Kempinas W.G.: Morphometric and biochemical evaluation 
of rat prostate and seminal vesicle following chemical sympathectomy with guanethidine. Arch. Int. Physiol. Biochem. 98, 225-230, 1990

Laufer N., May J.Y., Segal S., and Grover, N.B.: Size of rat spermatozoa during maturation along the epididymis. Arch. Andrology 3, 293-299, 1979.

Lavon U., Volcani R., and Danon D.: The proteins of bovine spermatozoa from the caput and cauda epididymis. J. Reprod. Fertil. 24, 219-232, 1971.

Lindahl P.E., and Thungvist L.O.: Specific gravity of epididymal and ejaculated bull spermatozoa and of their parts. Experientia $21,94-95,1965$.

Lowry O.H., Rosebrough N.J., Farr A.L., and Randall R.J.: Protein measurement with the Folin phenol reagent. J. Biol. Chem. 193, 265-275, 1951.

Monteleone P., Fuschino A., Nolfe G., and Maj M.: Temporal relationship between melatonin and cortisol responses to nighttime physical stress in humans. Psychoneuroendocrinology $17,81-86,1992$

Moore R.Y., and Klein D.C.: Visual pathways and the central neural control of a circadian rhythm in pineal serotonin $\mathrm{N}$ acetyltranferase activity. Brain Res. 74, 17-33, 1974.

Orgebin-Crist M.C., and Olson, G.E.: Epididymal sperm maturation. In The Male in Farm Animals Reproduction. (Ed. Courot M.), Amsterdam, Martinus Nijhoff, pp. 80-102, 1984.

Reiter R.J.: The role of light and age determining melatonin production in the pineal gland. In The Pineal Gland and Its Endocrine Role. (Eds. Axelrod J., Franchini F. and Felo G.P.), Plenum Press, New York, pp. 227-241, 1981.

Reiter R.J.: Pineal melatonin, cell biology of its synthesis and of its physiological interactions. Endocr. Rev. 12, 151-180, 1991.

Ricker D.D., Crone J.K., Chamness S.L., Klinefelter G.R., and Chang T.S.K.: Partial sympathetic denervation of the rat epididymis permits fertilization but inhibits embryo development. J. Androl. 18, 131-138, 1997.

Robaire B., and Hermo L.: Efferent ducts, epididymis, and vas deferens: structure, functions, and their regulation. In The Physiology of Reproduction. (Eds. Knobil E. and Neill J.D.), New York, Raven Press, pp. 27-68, 1988.

Shatz L., and Segal H.L.: Reduction of $\alpha$-keto-glutarate by homogeneous lactic dehydrogenase $\mathrm{X}$ of a testicular tissue. J. Biol. Chem. 244, 4393-4397, 1969.

Vermouth N.T., Ponce R.H., Carriazo C.S., and Blanco A.: Circadian rhythm of lactate dehydrogenase in rat testis. Comp. Biochem. Physiol. 78 B, 897-902, 1984.

Vermouth N.T., Carriazo C.S., Ponce R.H., and Blanco A.: Lactate dehydrogenase $\mathrm{X}$, malate dehydrogenase and total protein in rat spermatozoa during epididymal transit. Comp. Biochem. Physiol. 83 B, 381-384, 1986.

Vermouth N.T., Carriazo C.S., Gallará R.V., Carpentieri A.R., and Bellavía S.L.: Maternal coordination of the daily rhythm of malate dehydrogenase activity in testes from young rats:
Effect of maternal sympathetic denervation of the pinea gland and administration of melatonin. Chronobiology International $12,8-18,1995$.

Wroblesky F., and La Due J.S.: Lactic dehydrogenase activity in blood. Proc. Soc. exp. Biol. Med. 90, 210-213, 1955.

Wurtman R.J., Axelrod J., and Phillips L.S.: Melatonin synthesis in the pineal gland: control of light. Science 142, 10711073, 1963

Wurtman R.J. Effects of light and visual stimuli on endocrine function. In Neuroendocrinology (Eds. Martini L. and Ganong W.F.), Academic Press, New York, pp. 19-59, 1967.

Yanagimachi R.: Mammalian fertilization. In The Physiology of Reproduction, Second Ed. (Eds. Knobil, E. and Neill, J.D.), Raven Press, New York, pp. 189-317, 1994. 